\section{In the fight for racial justice, the sidelines are no longer an option}

\author{
Tracy Blake (1) 1,2,3
}

The British Journal of Sports Medicine (BJSM) has worked diligently to position itself as 'a multi-media platform that provides original research, reviews and debate relating to clinically-relevant aspects of sport and exercise medicine, including physiotherapy, physical

\footnotetext{
${ }^{1}$ Department of Physical Therapy, University of Toronto, Toronto, Ontario, Canada

${ }^{2}$ Volleyball Canda, Ottawa, Ontario, Canada

${ }^{3}$ University Health Network-Toronto Western Hospital,

Toronto, Ontario, Canada
}

Correspondence to Dr Tracy Blake, Department of Physical Therapy, University of Toronto, Toronto ON M5S, Canada; tracyablakeptphd@gmail.com therapy, and rehabilitation'. ${ }^{1}$ Its global community and partnership network includes well over 10000 sport and exercise medicine (SEM) physicians and sport physiotherapists-each with an ethical obligation to prioritise athlete health, safety and well-being. When the BJSM chooses to amplify an issue, the sport and exercise medicine community listens. When the BJSM chooses to remain silent, as it has on the impact of racism, colonialism and white supremacy on athlete health, safety and well-being, that silence speaks volumes.
Racism is a human rights issue and a public health issue. The murder of George Floyd has become the catalyst for reflection, reckoning and reform the world over. The BJSM is not exempt. Much like the Translating Research into Injury Prevention Practice model ${ }^{2}$ would suggest, the BJSM must better understand the presentation and burden of racism, colonialism and white supremacy, and identify factors that reinforce their presence and impact, be it implicitly, covertly or overtly.

Research and academic publishing have an inequity issue. The pervasive and persistent dominance of older, White, cisgender male voices has received much attention in recent years, including at the BJSM. The BJSM has both led and amplified actionable changes that have focused on disrupting and dismantling the bias towards the older, cisgender maleness of those dominating these spaces. Yet, the 
BJSM has not engaged in any actions to disrupt and dismantle the bias towards the whiteness of those dominating these spaces.

The quality of research is not reflected in its neutrality nor in its objectivity; it is reflected in its transparency. Concepts such as the biopsychosocial model, complex systems approach and the importance of sport in the context of public health are amplified across the BJSM platform. Yet there is rarely a mention of any social determinants of health, even descriptively. The impact of oppression in any iteration (eg, racism, misogyny, homophobia, transphobia, ableism, ageism, classism, religious bigotry, etc) on any component of the research process is never discussed.

The BJSM requires its authors to report their ethics approval, informed consent and completing interests. But no such standards have been implemented around the use (or lack thereof) of culturally competent research practices. Methods sections address how study participants are recruited, assessed, observed, evaluated and treated. But discussion regarding how the disparity between the racial demographics of a study population and the population of interest could impact a study's generalisability, for example, has been entirely absent.

The BJSM platform extends beyond peer-reviewed research articles and editorials to include blogs, podcasts, educational modules, conference accreditations and social media. That platform has been used to amplify issues and disseminate timely information for the sport and exercise medicine community. Thirty-two offerings, for example, were disseminated to help clinicians navigate the COVID-19 pandemic between 18 March and 12 June 2020. Yet, until now, none of these resources have been used to engage with the sport and exercise medicine community about how racism and other systems of oppression can be identified and dismantled within the US\$1 trillion sport-industrial complex. The apathetic response from the BJSM to the laundry list of examples of institutionalised and interpersonal racism experienced by Black, Indigenous, and people of colour within sport around the globe has not gone unnoticed.

These examples of omissions and oversights do not 'just happen'. They are predisposed to occur when there is a pattern of bias towards whiteness as the default. This is the foundational tenet of white supremacy. Acknowledging this is hard. Accepting it, even harder. But until we do, we cannot move towards accountability and actionable progress towards racial justice.

Racism is not extraneous to the sport and exercise medicine community. Its impact on athlete health, safety and well-being cannot be denied. Racism will not fade into obscurity and irrelevance simply by people not being racist; it must be addressed through intentionally antiracist actions. ${ }^{3} 4$ Every aspect of SEM scholarship-from the scientific paradigms we choose to value, ${ }^{5}$ to the publication and discourse policies we choose to enact ${ }^{6}$-must be re-examined and reformed accordingly. Indigenous Australian elder, artist, educator and activist Lilla Watson belonged to a collective from which the following quote arose: "If you have come here to help me you are wasting your time, but if you have come because your liberation is bound up with mine, then let us work together". Racial justice is more than just a pipe dream. Reform is possible. The time to act is now. The BJSM is not exempt.

Acknowledgements This article was written in Toronto, Ontario, Canada, on the traditional territory of many nations, including the Mississaugas of the Credit, the Anishnaabe, the Chippewa, the Haudenosaunee, and the Huron-Wendat peoples. This work would not be what it is without Jennifer Ogilvie and Winta Desta, whose justice-driven vision, critical consideration, reflective insight and emotional support were always right on point and right on time.

Contributors The author wrote, revised and edited this manuscript.

Funding The authors have not declared a specific grant for this research from any funding agency in the public, commercial or not-for-profit sectors.

Competing interests Dr Tracy Blake is an Associated Editor of BJSM.

Patient consent for publication Not required.

Provenance and peer review Not commissioned; internally peer reviewed.

(c) Author(s) (or their employer(s)) 2020. No commercial re-use. See rights and permissions. Published by BMJ.

\section{Check for updates}

To cite Blake T. Br J Sports Med 2020;54:1245-1246.

Accepted 15 June 2020

Published Online First 30 July 2020

Br J Sports Med 2020;54:1245-1246.

doi:10.1136/bjsports-2020-102894

ORCID iD

Tracy Blake http://orcid.org/0000-0002-1888-2940

\section{REFERENCES}

1 British Journal of sports medicine: aims and scope. Available: https://bjsm.bmj.com/pages/about/ [Accessed 10 Jun 2020].

2 Finch C. A new framework for research leading to sports injury prevention. J Sci Med Sport 2006;9:3-9.

3 Angela Davis 1983.

4 Kendi IX. How to be an antiracist. New York: One World, 2019.

5 Cormack D, Paine SJ. Dear epidemiology: a letter from two Māori researchers, 2020. Blog. Available: https:// www.pantograph-punch.com/posts/dear-epidemiology [Accessed 3 Jul 2020].

6 Boyd RW, Lindo EG, Weeks LD, et al. On racism: a new standard for publishing on racial health inequities, 2020. Blog. Available: https://www.healthaffairs.org/do/10. 1377/hblog20200630.939347/full/ [Accessed 2 Jul 2020].

7 Aboriginal Activist Group, Queensland. Blog, 1970. Available: http://northlandposter.com/blog/2006/12/ 18/lila-watson-if-you-have-come-to-help-me-you-arewasting-your-time-but-if-you-have-come-because-yourliberation-is-bound-up-with-mine-then-let-us-worktogether/ [Accessed 13 Jun 2020]. 